\title{
THE HISTORY OF MINE SURVEYING AND MINING MAPS
}

\author{
Gabriela OVESNÁ ${ }^{1}$, Hana STAŇKOVÁ ${ }^{2}$, Ladislav PLÁNKA ${ }^{3}$, Andrea WLOCHOVÁ ${ }^{4}$ \\ Institute of Geodesy and Mine Surveying, Faculty of Mining and Geology, \\ VSB - Technical University of Ostrava, 17. listopadu 15, CZ 70833 Ostrava, Czech Republic \\ E-mails: '1gabriela.ovesna@vsb.cz (correspondingauthor); ${ }^{2}$ hana.stankova@vsb.cz; \\ 3ladislav.planka@vsb.cz; ${ }^{4}$ andrea.wlochova@vsb.cz \\ Received 03 April 2017; accepted 16 August 2017
}

\begin{abstract}
The beginnings of the mining history date back to ancient times, up to the second century B.C. One field closely related to mining activities is mine surveying. Mine surveying and mapping are disciplines that deal with the surveying and displaying of underground works and mining claims, in which their spatial relationships are determined against the surface.

The introductory part of the paper is dedicated to the history and development of the mine surveying discipline and mapping, and to the profession of a mine surveyor. The second part of the article is devoted to historical mining maps produced in Austria, the Czech Republic and Slovakia. Historical mine maps belong to the significant treasures of past times, and from today's perspective they are often considered to be pieces of art. In the time of their origin they belonged to the most sophisticated technical-natural documents that were used for the registration of property rights, and for the performance of mining activities. With regard to the period in which they were created they are accurate, yet there are few records on their history.
\end{abstract}

Keywords: mine surveyor, history, historical mine maps, works of art, mining activities.

\section{Introduction}

Mining and related activities belong among the oldest technical disciplines that affected the development of states not only in the Czech basins. A field closely related to mining activities is mine surveying, together with the profession of a mine surveyor, who ensures the mine surveying works in mines, and on adjacent surfaces.

Mine maps provide evidence based on the excellent knowledge and experience of old mine surveyors or mining experts, and many historical mine maps contributed to the discovery of old flooded mine shafts and to various explorations. Historical maps or older maps are also widely used for rediscovering the old mining works of lignite mines that now are excavated using the opencast mining, e.g. in North Bohemian Mines.

\section{Mine surveying in the world}

Mine surveying operations are mentioned in the ancient cultures of Egypt, Babylon, China and India, which were very technically sound, and whose great constructions, such as pyramids, water works, and temples would not be possible to erect without these surveyors. Surveying works are reported on old wall paintings and in textbooks, in which they were depicted as sketches on papyrus, or as the land areas of cities and large territorial units.

The history of mine surveying has been, documented from the second century B.C., namely from ancient Rome. From that time there are mine works preserved that not only prove the mining skills, but also give us evidence of the surveyors' skills, who were able to drive mine works at that time. The connection between the mine and surfaces, and jobs related to these activities were described by Hérón of Alexandria in the second century B.C. In Ancient Rome, between the years 41 to 54 A. D., a drainage gallery was driven at Lake Fucino, for which mine surveying practice was used.

The Roman army also employed some very good surveyors. From the 1st century B.C. these surveyors were state officials, who were appointed to their positions on the basis of a test of expertise. 


\subsection{Mine surveying (Markscheider) in the Czech Lands}

The development of mine surveying in the Czech Lands is closely related to the development of mining activities in the territory of Bohemia, which has a long-standing tradition. As early as in the 13th and 14 th century the workers in Kutná Hora were facing issues, which other mine works started to deal with many centuries later. At that time miners in Kutná Hora were mining from 2 to 5 tons of silver per year, and the mine pits were 300 to $400 \mathrm{~m}$ deep. As the mining works were developing further, the requirements for a mine surveyor were on the increase, and that is why there were founded the first institutions dealing with surveying in Kutná Hora and Jihlava.

Among his obligations, such as staking measurements on the surface, a mine surveyor's task was to transfer milestones with so-called angular traverses into the underground, and thus decide about proprietary matters of miners.

When the deposits were mined out, which were formed by differently oriented veins, there was created a highly linked complex of mining works in the district of Kutná Hora. Operations in these complexes were managed and administered by a main miner and a mine surveyor. The supervision of mines, as stated e.g. in Zícha (2004), was primarily conducted orally, or if needed in some written form.

In the 14th century the work of a mine surveyor reached a high level of development. From the perspective of the uninformed public they were working with complex instruments and procedures when measuring on the surface and underground, which was considered to be a kind of art and it was called "Markscheidekunst". The field experience and the methods, which they used to measure the surface and underground, were not employed for mine surveying in the Czech Lands only, but e.g. in 1364 the Republic of Venice hired 25 miners from Kutná Hora that helped their army to establish underground passages to conquer towns and fortresses in Crete.

The first historically extensive references concerning the execution of mining disciplines can be found in the work of Georgio Agricola De re metallica libri XII or The Twelve Books on Mining and Metallurgy, which the author wrote for more than 20 years. He finished the monograph in 1550 and it was published in 1556 in Basel, a year after Agricola's death. This historical work met with a great response. Agricola dedicated the fifth book to mine surveying, called On the extraction of veins and the art of a surveyor, in which he describes the operations of a mine surveyor: e.g. the use of a main compass to measure the underground works, for the mine surveying of works, and for connecting and orientation surveys. For more information about Agricola's work The Twelve Books on Mining and Metallurgy.

\subsection{The activities of the mine surveyors "Markšajdrư"}

The function of these "Markšajdrs" (mine surveyors) was defined in the Jihlava Mining Law in 1249. This law was followed by The First Mining Law of King Wenceslas II from the year 1300, issued in Kutná Hora. These are the oldest written records concerning the management of mine surveying documentation, which were at that time (Zícha 2004) binding for mining laws and mining courts. The main role of mine surveyors was to provide all the survey work related to mining activities, for example the tracing and recording of seam thicknesses and their categorization, seam arrangement, tectonics, the amount of extracted raw material, and the mutual relations between the underground and the surface. If a mine surveyor did poor work while surveying, he was punished, as he was personally responsible for the measurements. Mine surveyors in the 18th century, were assigned also other work, such as the construction of transport routes, water works, etc. To be able to meet all of the survey tasks, they had two helpers, usually some students of Mining Academies.

\subsection{The name of the mine surveyors}

At the very start of mining activities mine surveyors were called "hormistři" (minemasters). In The Royal Law of Miners there is the term "dolový měrič" (a mine pit surveyor) used. In the Jachymov Mining Code it is "př́sežný důlní měřič" (a statutory mine surveyor). The mining law from 1548 mentions the term "perkmistr" (from the German language).

From mining regulations written in 16th century it is clear that the position of a mine surveyor was held only by a "statutory mine surveyor". Around 1855 we are talking about so-called "royal mine surveyors"; those people should have a greater scope of mine survey work, thanks to the growing number of coal mines (Jadviščok et al. 2014).

\subsection{Mining education}

With the development of the mine surveyor profession there was the first mining college in the world opened in Jáchymov in 1716, which offered education in mine 
surveying and mapping. In 1753, during the reign of Marie Therese, a theoretical department of all mining sciences was established at Charles University in Prague, which bore the name "Academia Metallurgie". In 1780 this university studies were transferred to Banská Štiavnice, which was then the most famous mining town in the whole Austrian Empire (the Habsburg monarchy). In the literature it is also mentioned that in year 1764 in Banská Štiavnica the Vysoká škola báňská - Báňská akademie (the University of Mining - Mining Academy) was established. Before the establishment of the university there was a vocational school opened there in 1735 . Surveying methods and different ways of mapping, taught at this school, were later spread to various parts of Europe, and even to overseas countries.

New schools were founded after the release of the Emperor's Patent in 1849. For Austrian countries a school in Príbram was founded, and there the first professor of mining was the emperor's royal mine surveyor and supervisor Karel Heyrowský. In 1894 the Mining Academy in Př́bram was promoted to a university. The name "University of Mining in Přibram" was assigned with all the rights and obligations of the universities on the 31th of July 1904 . Vienna tried hard to reduce the number of mining schools in Bohemia to only one. After a large mining accident the authorities realized that it was necessary to ensure safety in mines and to educate mine managers, who would graduate from one of the universities, and would know the local conditions in the district well.

Mine surveying underwent great development. The process was encouraged by a good quality education and teaching, the available literature, the invention of instruments and equipment, which facilitated the work of mine surveyors. And all this was able thanks to the expansion of the mining and coal industry.

Currently in the Czech Republic the only university programme on "Mine Surveying" is offered at the Faculty of Mining and Geology at Vysoká škola báňská - Technical University of Ostrava, which offers Bachelor's, Master's and Doctoral Study programmes. In Slovakia it is possible to study it within the doctoral programme Mining Surveying and Geodesy at the Faculty of Mining, Ecology, Process Control and Geotechnologies, at the Technical University of Košice.

\section{The oldest mine maps}

One of the oldest known mining maps comes from about 1500 B.C. It illustrates the mining of gold and it is preserved in Turin. One interesting fact is that before real mining maps occurred, in the 16th century in e.g. in Austria and Germany the spatial relations for mining works and other knowledge on the mining work were depicted on a scale of 1:1. As a suitable surface to display the situation there was used e.g. the frozen surface of lakes in the Alps or, as stated in Stadtarchaeologie-hall (2012), open spaces such as the meadows west of Innsbruck, where networks of adits were displayed using pins and ropes.

In accordance with Stadtarchaeologie-hall (2012) we can mention one of the oldest known mining maps in Austria, the mining map of the salt mines in Tyrolean Halle, which comes from the year 1531. This deals with the first mine map of Hallstätter Salzberg, which is considered to be an innovation in the history of alpine mining, as there are not any earlier mining maps in the entire territory preserved. The size of this map is $114 \times 214 \mathrm{~m}$, and it is drawn on a scale of 1:600. Its author is Limburger. This map is deposited in the archives of the Salinen Austria, at Ischl Spa. Another similar map, in which a salt mine in Salzburg is depicted, comes from 1534.

\subsection{The oldest mine maps in the Czech Lands}

The first information on mine cartographic works in our countries, belong to the end of the 15th century. Evidence of it can be found in the Kutnohorský antifonár from 1471 (see Fig. 1) and mainly on the title page of the Kutnohorský hymn book (mass songbook) from 1490 (see Fig. 2), where in the lower part of this

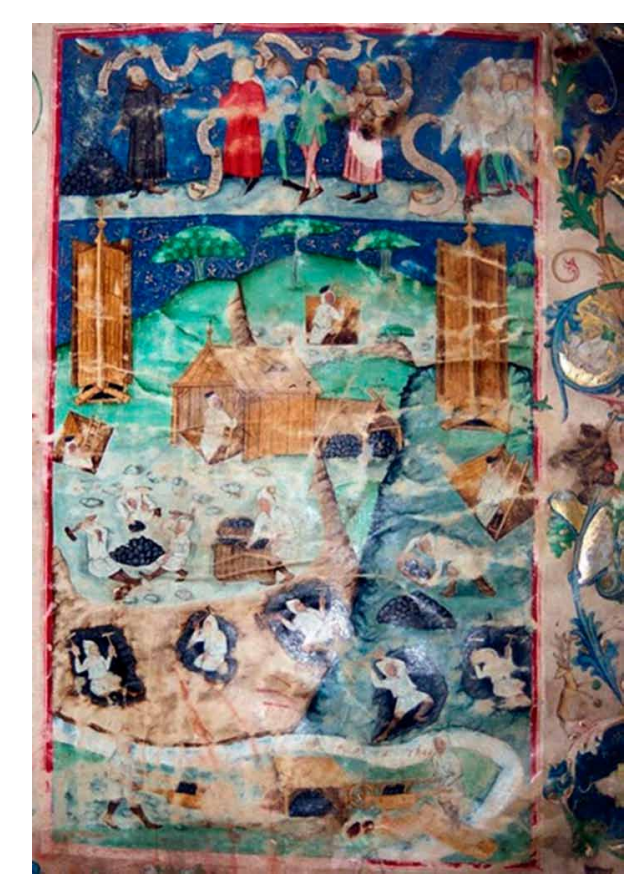

Fig. 1. Introductory page of the Kutnohorský antifonár with a picture of mining in Kutná Hora 
work you can find an illustration "in a scale" showing the cross-section of the Kutná Hora mining works, depicted with the equipment and miners.

This drawing is accompanied by a view of the mining and ventilation shaft on the surface. You can also see the terrain of the mine with buildings on the surface.

The mining maps of Kutná Hora belong not only to the oldest maps in our territory, but also to the historical monuments of mining in Kutná Hora.

The oldest and the most important mining map in Bohemia is the map of ore mines, which shows the Poličany adit in Kutná Hora, which originated in 1534. The author of this adit map for the Poličany adit is Zikmund Prášek, who created it using a mining dial. This map captures almost all important principles of mining cartography, and has descriptions written in Czech. The mine site map is also called "the dial map", and it represents a ground plan projection of an adit, designed using surveying dial traverses. This map can be considered as one of the

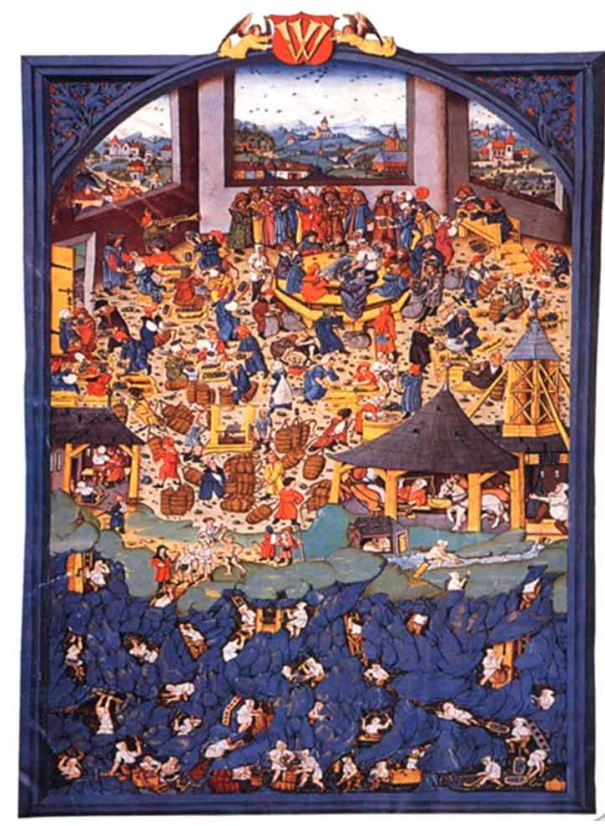

Fig. 2. Introductory page of the Kutnohorský mass songbook

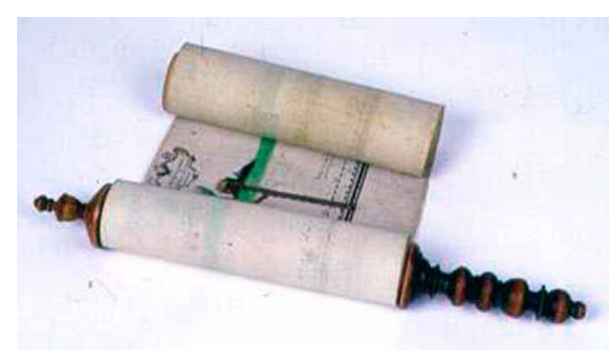

Fig. 3. Phendler's map on a wooden roller oldest in the world. The original of the map is stored in the State Regional Archive in Kutná Hora. Its size is $410 \times 205 \mathrm{~mm}$ and is drawn on a scale of 1:320. (Staňková, Černota 2013)

Among the oldest mining maps in Central Europe a unique Freiber map from 1529, made by perkmistr Köhler, can be included. Unfortunately, its original copy did not survive, only a copy from the 17 th century.

Among other perfect and advanced maps belongs the map of site stops for the Panenská Adit, which belonged to Jiřík from Řásná, originated in 1578. This map aided in the 1940s with the modern geological survey in the verification of the old flooded stopes, used in the process of reopening the mine. Mining maps from the second half of the 16th century reached, for its time, an excellent technical level. Among these mining maps we can find the above mentioned mining map of Jiř́k from Řásná, a plot view of the mines Frátny and Šmitna in Kutná Hora from 1583, by the same author, and the mining map for locations in Hřebečná u Jáchymova dated from 1562.

One of the first works of Czech and European mining cartography is Rudolf's Adit in Prague. As a mine surveyor Jiří Oeder from Ústí was invited to set-out the direction of this adit, accompanied by five vertical shafts, in the spring of 1582 . In 1593 Isaac Phendler began to draw a map of the Rudolf's Adit, (see Fig. 7) and recorded the course of the work during the tunnelling process week after week. Then there are marked places where the miners met during the tunnelling, with exact times. Thanks to this plan we know exactly how much rock was extracted per month. The map is drawn very carefully on a piece of parchment $198 \mathrm{~mm}$ wide, and approximately 2420 $\mathrm{mm}$ long. The drawing itself covers $2133 \mathrm{~mm}$. As can be seen in Figure 3 a wooden roller is attached to the left edge to wind the map up. In 1648 Phendler's map was stolen by Swedish troops during the Thirty Years' War at the behest of Queen Kristina I. It is now displayed in the National Technical Museum. Queen Kristina I. probably took this map to Rome, and from there the map got to Paris, where at the end of the 19th century it was discovered in a shop of antiquaries by Dr Schebek, who bought it for the collection of the famous entrepreneur Vojtěch Lanna. During an auction the imperial councelor František Borovský bought this map and gave it to the Technical Museum of the Bohemian Kingdom, today's National Technical Museum. There it has been stored since 1910, under number 1848. 


\subsection{The oldest mine maps in Slovakia}

Until the 16th century there were no data available on mining maps originated in Slovakia. But from the 17th century we know of several mining maps. As the private mining-company founders tried to cover up their mines, they were against drawing maps. From this century we know about a mine surveyor Matěj Ethesius, who worked in Španá Dolina from 1685 to 1689.

The collection of lectures from the conference "Mining maps - in history and the present" organized in 1992 in Kutná Hora mentions a map from 1569, which should be the oldest map in Slovakia. It is a map of Boží dar in Jarabá. The other known mining map is a map from 1591, in which you can find the hereditary adit Krebsgrund in Bánská Štiavnica.

In the archive of the Head Komorsky gróf Authority in Bánská Štiavnica, houses the oldest map of the mentioned stock, which comes from 1641. This deal with a mining map of Horna Bíberová štôlna in Vindšachta, drawn by an unknown creator, where we can see the whole complex of the underground mining works, and the surface objects. Unfortunately, this historical treasure was damaged in the past, and thus become illegible (see Fig. 4).

The development of mine surveying and mapping in Slovakia started from the 1740s. The growing number of mining maps dates from the time when the Mining Academy in Banská Štiavnica was established in 1780 . From the 1740s till the 1930's many technically perfect maps were drawn, which provide accurate data on mining works.

\section{Conclusion on the history of mining maps and mine surveying}

Until the 16th century mine maps were drawn rarely. They originated from the mid 16th century in mining towns such as Př́bram, Rudolfov, Horní Slavkov, Český Krumlov and in other mining areas in the Czech Lands.

From the 16th century we can find more than thirty mining maps, which we can consider to be a proof of the development in mine surveying and mine mapping in the Czech Lands, while in the neighbouring countries in the same period few mining maps can be found. In Austria, e.g. there are six, in Germany approximately seven, in the former Austria-Hungary four, and in Poland only one.

In the 17th century there was a decline of mining, which affected almost the whole of Czech

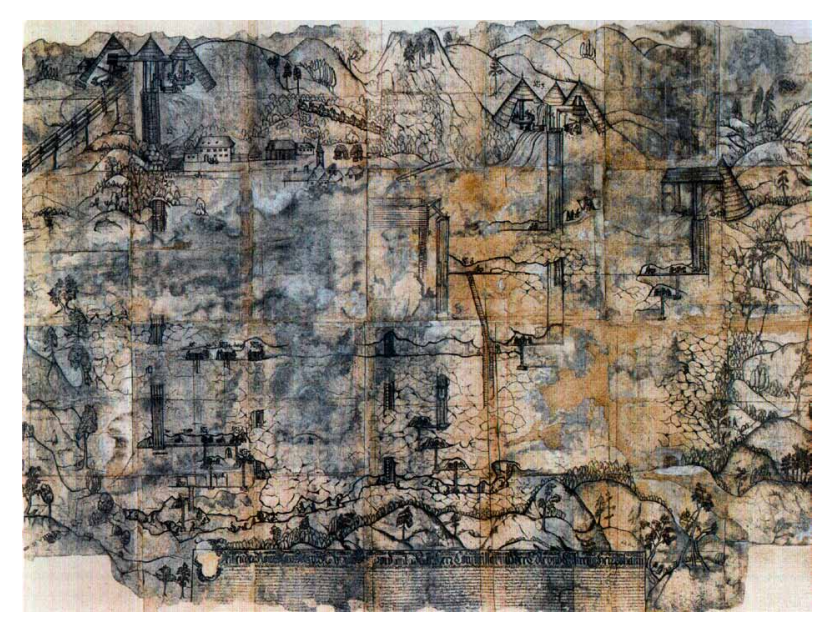

Fig. 4. The oldest map of the Head Komorsky Grof Authority

Mining, and therefore the development of mine surveying and mapping was set back, while newly created maps are kept in the same number as it was in the 16th century. In their contents some evidence of elements and characters relating to their German origin can be found.

Until the18th century greater emphasis was put on the artistic design and decorativeness of maps than on the accuracy and clarity of these maps. Since the mid 18th century a new renaissance period of the mine surveying and mining cartography has been recorded, because there was great demand for the extraction of precious metals. Numerous explorations of abandoned ore mines took place for their reopening, as well as in planning of new ones. In that period various maps were drawn with varying technical quality, yet they are unique in particular for the scale used. Progress in technologies influenced the maps development as well, together with the science on mining industry. More advanced instruments were designed, such as the dial, astrolabe, and other devices which contributed to the greater accuracy of mining maps, and facilitated the work of the mine surveyors.

Since the 16th century to the middle of the 19th century approximately five thousand maps with elements of mining have been preserved. These maps present the amazing technical and artistic skills of the mine surveyors and mining maps cartographers.

Mine surveying and cartography deals primarily with the measuring and displaying of underground works and mining areas, in which their spatial relations towards the surface are determined.

This article deals with the historical development of mine surveying, mining cartography, and mining maps. 


\section{References}

Jadviščok, P.; Dandoš, R.; Jiroušek, T. 2014. Measurement of verticality construction of bushings for laboratory construction materials, Geodesy and Cartography 40(4): 171-174. https://doi.org/10.3846/20296991.2014.987458

Stadtarchaeologie-hall. 2012. Die erste Grubenkarte des Haller Salzberges [online], [cited 3 April 2017]. Available from Internet: http://www.stadtarchaeologie-hall.at/downloads/ hb_nov_2012.pdf

Staňková, H.; Černota, P. 2013. Application of Ott‘s mine coordinate system in the past and in present day, Geodesy and Cartography 39(2): 53-58. https://doi.org/10.3846/20296991.2013.806696

Zícha, Z. 2004. Dưlní mapy a měřické přistroje. Díl I. Ústí nad Labem: CDL Design.
Gabriela OVESNÁ. Ing., VŠB - TU Ostrava, Institute of Geodesy and Mine Surveying, Faculty of Mining and Geology, VSB Technical University of Ostrava, Ostrava, Czech Republic.

Research interest: the deformations in the building construction of the bridge, history of mine surveying and mining maps.

Hana STAŇKOVÁ. doc, Ing., Ph.D., VŠB - TU Ostrava, Institute of Geodesy and Mine Surveying, Faculty of Mining and Geology, VSB - Technical University of Ostrava, Ostrava, Czech Republic.

Research interest: geodesy, surveying, engineering surveying.

Ladislav PLÁNKA. RNDr., CSc, VŠB - TU Ostrava, Institute of Geodesy and Mine Surveying, Faculty of Mining and Geology, VSB - Technical University of Ostrava, Ostrava, Czech Republic.

Research interest: cartography, remote sensing, The history of surveying.

Andrea WLOCHOVÁ. Mgr., Ph.D., VSB - Technical University of Ostrava, Ostrava, Czech Republic.

Research interest: English language. 